\title{
An Assessment of the Proximate Composition and Antibacterial Activity of Crinum Zeylanicum Bulb Extracts Used in the Treatment of Bone Setting and Healing
}

\author{
Daben, J. M ${ }^{1}$, Dashak, D. A², Daben, M.R ${ }^{1}$, Jock, A.A ${ }^{1}$, Onaji, J.O ${ }^{1}$. \\ ${ }^{I}$ Department of Science Laboratory Technology, \\ ${ }^{2}$ Department of Chemistry, Faculty of Natural Sciences, University of Jos, Jos, Plateau State, Nigeria.
}

\begin{abstract}
The proximate composition and antibacterial activity of Crinum zeylanicum bulb was evaluated with the aim of understanding the rationale usage by herbal traditional practitioners on trouble skin and bone setting/healing. Aqueous, ethanol and n-hexane extracts were tested on Staphylococcus aureus, Streptococcus pneumoniae, Bacillus cereus, Escherichia coli, Salmonella typhi and Shigella dysenteriae using the agar well diffusion technique and zones of inhibition in diameter. The proximate parameters analyzed revealed the presence of moisture $(39.58 \% \pm 1.16)$, ash $(6.26 \% \pm 2.13)$, crude fiber $(26.55 \% \pm 0.68)$ crude fat $(5.00 \% \pm 0.00)$, total carbohydrate $(43.95 \% \pm 2.15)$, nitrogen $(0.51 \% \pm 0.06)$, crude protein $(3.19 \% \pm 0.01)$ and reducing sugar (0.49), The antibacterial screening results revealed that the aqueous extract showed marked inhibitory effect on the test organisms than other extracts at significant difference of $\leq 0.01$ and more pronounce on S.pneumoniae while S. aureus was found to be the most sensitive toward antibacterial activity of ethanol extract and then the $n$-hexane extract showed no activity on the test organisms except for $S$. pneumoniae at $\left(400-50 \mathrm{mg} / \mathrm{cm}^{3}\right)$ concentrations and at $400 \mathrm{mg} / \mathrm{cm}^{3}$ for S. aureus. The MIC and MBC for the three extracts also concurred that water extract have higher potential of preventing the activity of the bacteria than the ethanol and n-hexane extracts. These results indicate that the bulb of $C$ zeylanicum contained essential nutrients and antibacterial effects suitable for health benefit as it explained the medicinal action of the plant encountered in its therapeutic uses
\end{abstract}

Keywords: Antibacterial activity, bone setting/healing, Crinum zeylanicum bulb, proximate composition, herbal medicine.

\section{Introduction}

The study of traditional human uses of plants is recognized as an effective way to discover future medicines. This discovery of pharmacopoeia of scientific medicine, which was derived from the herbal knowledge of native people simply because of the search of new type of food, has help the growth of modern medicine in the developing country. It has been noted that $80 \%$ of modern medicine which were derived from traditional plants sources; has had a traditional use identical or related to the current use of active elements of the plants [1]

In light of this, medicinal plant are no longer considered new resources for producing effective agent that could act as alternatives to anti-biotic in the treatment of antibiotic-resistance bacteria, which are considered one of the important reason for lack of success of treatment in some infectious diseases. All plants produce chemical compounds as part of their normal metabolic activities which meditate their effects on human body through processes identical to those already well understood for convectional drugs; thus herbal medicine do not differ greatly from convectional drugs in terms of how they work [2].

Infectious diseases have been an important cause of morbidity and mortality through developing countries history. Treatment of infectious diseases becomes more challenging with each passing year. With the expansion of antibiotic era during the $20^{\text {th }}$ century, there was a growing confidence that the need for infectious disease specialists would all but disappear. The ability of pathogens to adapt and to overcome the challenges of antibiotics in their environment has been nothing short of impressive. The infection caused by the opportunistic pathogen Pseudomonas aeruginosa, with its ability to rapidly develop resistance to multiple classes of antibiotic an example that is still lingering [3]. It has become more important to develop our phyto-based health products which have fewer side effects and has gained an increasingly attention by the populations in most developing countries like Nigeria. Poverty and lack of access to existing essential medicines making the numbers of Traditional Health Practitioners (THPs) outnumbering the Conventional Health Practitioners (CHPs). However, traditional practices continue to maintain its popularity for historic and cultural reasons. Crinum zeylanicum (L.) is one of the medicinal plants that has gained popularity in the areas of traditional practices. C.zeylanicum is common from Senegal to west Cameroun, Nigeria to West Africa and throughout tropical Africa [4] and sub- 
tropical part of the world-Sri-lanka [5]. C.zeylanicum is bulbous plant and can be grown from dormant bulbs gathered during dry season on a temperate and warm temperate region [5].

The plant is called Dau (Doemak) and Le'zipir (Mushere) of Plateau state of Nigeria, commonly used to treat various ailments. Personal interaction with the herbal practitioners and the practices in the state indicate that the fresh crushed bulbs acts as surfactant for bone setting/healing when an incision is made around the fracture/bone. The non-solvent crushed bulbs are introduced around the flesh in the fracture areas and tied for 5-7 days before examination, other uses are treatment of skin troubles like boils, eczema and guinea worms blister.

The bulb extracts are also used for treatment of rubefacient in rheumatism, ear ache and malaria [6,7]. The plant is found to be effective in control of molluscan, which is an intermediate host of Schistosomiasis $[6,8]$. The alkaloids; Crinidine, Flexinine, 6-hydroxypowelline, Zeylamine, Lycorine, Hamayne, 3-acetylhamayne, Crinamine, 6-hydroxycrinamine, 6-methoxycrinamine and Galanthamine have been isolated from the extract of Crinum zeylanicum including many bioactive compounds which exert anti-proliferative effects against humane tumor cell $[9,10]$. Thus, this specie have cultural and medicinal significant among the region. Although no antibacterial properties have been reported for this specie but related work on methanol bulb extract ointment have proof effective on wound healing on Wister rat and have neutro-pharmaceutical effect on mice [11].

Proximate parameters are used in the analysis of biological materials as a decomposition of humanconsumable goods into its major constituents. This serve as a cheap and easy verification of nutritional contents; good approximation and quick estimation of nutrient potentials of feedstuff extensively employed in researches and industries for they are clue to research for plants of potential value for further work [12].

The alarming rate of increase in the development of resistant mutant of bacteria pathogen to synthetic antibiotic necessitates interest in the uses of medicinal plant to treat infectious diseases caused by pathogenic bacteria such as Shigellia dysenteriae, Escherichia coli, Bacillus cereus, Staphylococcus aureus, Streptococcus pneumoniae and Salmonella typhi and to examine the nutritive potentials of the bulb. This is because of general acceptability that phyto-based health products have fewer side effects [11].

\subsection{Sample Collection and Preparation.}

\section{Material And Methods}

Crinum zeylanicum bulbs were obtained from Organic garden in Kopmabar, Doemak District in Qua'an Pan and Ikgwakap-Mushere in Bokkos Local Government Areas (LGAs) of Plateau State-Nigeria. The samples was stored in plastic containers and transported to the laboratory for analysis. Samples were cleaned free of debris, air-dried, milled and stored in an airtight container for analysis [13].

\subsection{Preparation and Concentration of Extract}

Fifty grams $(90 \mathrm{~g})$ of the sample powder was extracted with soxhlet extractor using $250 \mathrm{~cm}^{3}$ each of the solvents (n-hexane, Ethyl acetate and ethanol). The extracts were concentrated by the use of vacuum rotary evaporator at $35^{\circ} \mathrm{C}$.

\subsection{Proximate Analysis}

Each treatment was replicated three times; the proximate analysis content were moisture, ash, crude fat, crude fiber, crude protein, total carbohydrate, reducing sugar, and nitrogen. These parameters were analyzed using the following methods or procedures according to [14] Moisture content was determined by oven dried method. $5 \mathrm{~g}$ of the fresh sample was oven dried at $105^{\circ} \mathrm{C}$ for $24 \mathrm{hrs}$, transferred into desiccators to cool after which was weighed and the loss in weigh was expressed as percentage moisture content. Ash content was achieved by muffle furnace ashing method. $2 \mathrm{~g}$ moisture free sample were transferred into a porcelain crucible and placed in a muffle furnace at $600^{\circ} \mathrm{C}$ for $8 \mathrm{hrs}$. The weight after cooling the ash was expressed as percentage ash content. Crude fiber content was obtained by muffle furnace ashing method. This was achieved by loss in weigh on ignition of dried lipid free residues after digestion with $200 \mathrm{ml}$ of $1.25 \mathrm{~N} \mathrm{H}_{2} \mathrm{SO}_{4}$, and $200 \mathrm{ml}$ of 1.25 $\mathrm{NaOH}$ boiled with 3 lots of acetone, dried for $24 \mathrm{hrs}$ at $105^{\circ} \mathrm{C}$ in an oven. Weighed and ashed at $600^{\circ} \mathrm{C}$ for $6 \mathrm{hrs}$. The percentage crude fiber was calculated as the difference in weight between residue and ash. Crude fat content was analyzed by soxhlet extraction method using petroleum ether $60-80^{\circ} \mathrm{C}$. After being dried in an oven maintained at $105^{\circ} \mathrm{C}$ for 24 hours, cooled and weighed. The loss in weigh of the dried sample was expressed as percentage fat content. The value of crude protein content was determined by micro-kjeldahl method. The method involved the determination of total Nitrogen content of the sample and multiplying by a conversion factor of 6.25 as described by [15]. Total carbohydrate and Reducing sugar were determined using L-cysteine suphuric acid method and Nelson method respectively [16]. 


\subsection{Test Organisms and their Preparations.}

Pure isolate of Escherichia coli, Staphylococcus arueus, streptococcus pnuemoniae, bacillus cereus, salmonella typhi and Shigella dysenteriae were obtained from the Department of Microbiology, University of Jos, Plateau State, Nigeria. The bacterial were kept on nutrient Agar (NA) slant at $4^{0} \mathrm{C}$. Inoculations were obtained from overnight culture grown on NA slant at $37^{\circ} \mathrm{C}$.

\subsection{Determination of Anti-bacterial Activity of Etracts}

Agar well diffusion method as described by [17] was use for the antibacterial screening. $4 \mathrm{~g}$ of the crude extract was dissolved in $10 \mathrm{~cm}^{3}$ of distilled water to obtain $400 \mathrm{mg} / \mathrm{cm}^{3}$ as the highest stock solution. It was then serially diluted using the procedures of $[18,19]$. Gentamycin at $4 \mathrm{mg} / \mathrm{cm}^{3}$ was included as positive control. The sterilized molten nutrient Agar at $45^{\circ} \mathrm{C}$ was set on the disinfected plates and equidistant wells on the surfaces of the agar were bored using a sterile cork borer of $4 \mathrm{~mm}$ diameter. $0.2 \mathrm{ml}$ of prepared extracts of different concentrations as well as the standard drug was transferred into the made holes of the agar. The culture plates were allowed to stand for 30 mins for pre-diffusion and the bacterial were incubated for 24 hours at $37^{\circ} \mathrm{C}$ after which the zone of inhibition were measured.

\subsection{Determination of Minimum Inhibition Concentration.(MIC)}

A double dilution of the extracts solutions $400 \mathrm{mg} / \mathrm{ml}, 200 \mathrm{mg} / \mathrm{ml}, 100 \mathrm{mg} / \mathrm{ml}, 50 \mathrm{mg} / \mathrm{ml}$ and $25 \mathrm{mg} / \mathrm{ml}$ were prepared in the nutrient broth accurate volume of $0.1 \mathrm{ml}$ of the suspension of an overnight culture of the test bacterial were added to respective sets of the test tube. After shaking to mix, the test tubes were incubated at $37^{\circ} \mathrm{C}$ for 24 hours in an incubator. The test tubes were examined for turbidity. The presence of the turbidity indicated growth in the test bacterial. The highest concentration that inhibited visible growth of the bacterial was observed and recorded as Minimum Inhibitory Concentration (MIC) of the extracts for that particular organism. The test was conducted under aseptic conditions.

\subsection{Determination of Minimum Bactericidal Concentration (MBC) of the Extracts}

The Minimum Bactericidal Concentration of the extracts that eliminate the test bacteria is known as Minimum Bactericidal Concentration. This is done in sub-culturing the contents of the test tubes that shows no growth in the (MIC) determination. Sub-culturing was done by streaking of loopful of the required MIC test tubes over the surface of the already set agar. This was incubated overnight at $37^{\circ} \mathrm{C}$ for 24 hours. The MBC was recorded as the lowest concentration with no growth observed on the nutrient agar plates.

\subsection{Statistical Analysis.}

The results of the statistical analysis were produced in triplicate and the percentage, mean, standard errors, were calculated by ibmSPSS version 23 and results expressed as the \%Mean \pm SEM. Mean values were separated using Duncan Multiple Range Test.

\section{Results}

Table 1: Proximate Composition of Crinum zeylanicum Bulb

\begin{tabular}{lc}
\hline Parameter determined & \% composition \\
\hline Moisture content & $39.58 \pm 1.16$ \\
Ash content & $6.26 \pm 2.13$ \\
Crude fiber & $26.55 \pm 0.68$ \\
Crude fat & $5.00 \pm 0.00$ \\
Total carbohydrate & $43.95 \pm 2.15$ \\
Nitrogen & $0.51 \pm 0.06$ \\
Crude protein & $3.19 \pm 0.01$ \\
Reducing sugar & 0.49 \\
\hline
\end{tabular}

$( \pm)=$ Standard Error of the Mean (SEM)

Table 2: Susceptibility Profile of the test organisms to Different concentration of the Aqueous Extract

\begin{tabular}{lcccccc}
\hline \multirow{2}{*}{ Concentration $\left(\mathbf{m g} / \mathbf{c m}^{\mathbf{3}}\right)$} & \multicolumn{5}{c}{ Mean \pm SEM } \\
\cline { 2 - 7 } & S. aureus & S. pneumoniae & B. cereus & E. coli & S. Typhi & S. dysenteriae \\
\hline 400 & $19.00 \pm 0.58^{\mathrm{b}}$ & $20.00 \pm 1.15^{\mathrm{a}}$ & $12.00 \pm 1.15^{\mathrm{b}}$ & $11.50 \pm 0.87^{\mathrm{a}}$ & $13.00 \pm 1.15^{\mathrm{b}}$ & $18.00 \pm 0.58^{\mathrm{a}}$ \\
200 & $18.00 \pm 0.87^{\mathrm{bc}}$ & $17.00 \pm 0.58^{\mathrm{b}}$ & $11.00 \pm 1.15^{\mathrm{bc}}$ & $11.00 \pm 1.15^{\mathrm{a}}$ & $11.00 \pm 1.15^{\mathrm{bc}}$ & $17.00 \pm 1.15^{\mathrm{ab}}$ \\
100 & $18.00 \pm 0.58^{\mathrm{bc}}$ & $11.50 \pm 0.87^{\mathrm{c}}$ & $10.50 \pm 0.87^{\mathrm{bc}}$ & $10.00 \pm 0.00^{\mathrm{ab}}$ & $10.00 \pm 0.00^{\mathrm{c}}$ & $14.00 \pm 1.73^{\mathrm{bc}}$ \\
50 & $16.00 \pm 0.50^{\mathrm{c}}$ & $11.00 \pm 1.15^{\mathrm{c}}$ & $8.00 \pm 1.15^{\mathrm{cd}}$ & $10.00 \pm 0.00^{\mathrm{ab}}$ & $7.00 \pm 0.58^{\mathrm{d}}$ & $12.33 \pm 0.88^{\mathrm{c}}$ \\
25 & $8.00 \pm 1.15^{\mathrm{d}}$ & $9.00 \pm 0.58^{\mathrm{c}}$ & $7.00 \pm 0.58^{\mathrm{d}}$ & $7.00 \pm 0.58^{\mathrm{b}}$ & $6.00 \pm 0.58^{\mathrm{d}}$ & $9.00 \pm 0.58^{\mathrm{d}}$ \\
Control & $25.00 \pm 0.58^{\mathrm{a}}$ & $18.00 \pm 0.58^{\mathrm{ab}}$ & $17.00 \pm 0.58^{\mathrm{a}}$ & $13.00 \pm 2.31^{\mathrm{a}}$ & $18.00 \pm 0.58^{\mathrm{a}}$ & $20.00 \pm 0.00^{\mathrm{a}}$ \\
ANOVA & 54.300 & 27.226 & 13.782 & 3.129 & 31.036 & 17.050 \\
p-value & $<0.001^{* *}$ & $<0.001^{* *}$ & $<0.001^{* *}$ & $<0.001^{* *}$ & $<0.001^{* *}$ & $<0.001^{* *}$ \\
\hline DOI: $10.9790 / 5736-1006025560$ & \multicolumn{2}{c}{ www.iosrjournals.org } & $57 \mid$ Page
\end{tabular}


Values are means of triplicate readings. Mean values were separated using Duncan's Multiple Range Test. Mean values with different superscripts in the same column are significantly different.

$*=$ significant difference exists at $\mathrm{p} \leq 0.05$

$* *=$ significant difference exists at $\mathrm{p} \leq 0.01$

Table 3: Susceptibility Profile of the test organisms to Different concentration of the Ethanolic Extract

\begin{tabular}{lcccccc}
\hline \multirow{2}{*}{ Concentration $\left(\mathbf{m g} / \mathbf{c m}^{3}\right)$} & \multicolumn{5}{c}{ Mean \pm SEM } \\
\cline { 2 - 6 } & S. aureus & S. pneumoniae & B. cereus & E. coli & S. Typhi & S. dysenteriae \\
\hline 400 & $18.33 \pm 0.17^{\mathrm{b}}$ & $13.00 \pm 2.31^{\mathrm{ab}}$ & $12.00 \pm 1.15^{\mathrm{b}}$ & $11.33 \pm 0.88^{\mathrm{b}}$ & $16.00 \pm 0.58^{\mathrm{a}}$ & $15.50 \pm 0.87^{\mathrm{b}}$ \\
200 & $17.67 \pm 0.73^{\mathrm{b}}$ & $12.00 \pm 1.15^{\mathrm{bc}}$ & $11.33 \pm 0.88^{\mathrm{bc}}$ & $10.50 \pm 0.87^{\mathrm{bc}}$ & $12.00 \pm 1.15^{\mathrm{b}}$ & $12.00 \pm 1.15^{\mathrm{c}}$ \\
100 & $12.00 \pm 1.15^{\mathrm{c}}$ & $10.00 \pm 0.00^{\mathrm{bc}}$ & $10.00 \pm 0.00^{\mathrm{c}}$ & $9.00 \pm 0.58^{\mathrm{c}}$ & $10.00 \pm 0.00^{\mathrm{b}}$ & $12.00 \pm 1.15^{\mathrm{c}}$ \\
50 & $11.33 \pm 0.88^{\mathrm{c}}$ & $9.50 \pm 0.87^{\mathrm{bc}}$ & $9.00 \pm 0.58^{\mathrm{cd}}$ & $8.00 \pm 1.15^{\mathrm{cd}}$ & $7.00 \pm 0.58^{\mathrm{c}}$ & $11.33 \pm 0.88^{\mathrm{cd}}$ \\
25 & $10.00 \pm 0.00^{\mathrm{c}}$ & $8.00 \pm 1.15^{\mathrm{c}}$ & $8.50 \pm 0.87^{\mathrm{d}}$ & $7.00 \pm 0.58^{\mathrm{d}}$ & $6.50 \pm 0.87^{\mathrm{c}}$ & $9.00 \pm 0.58^{\mathrm{d}}$ \\
Control & $25.00 \pm 0.58^{\mathrm{a}}$ & $16.00 \pm 0.58^{\mathrm{a}}$ & $16.00 \pm 0.58^{\mathrm{a}}$ & $16.00 \pm 0.58^{\mathrm{a}}$ & $18.00 \pm 0.58^{\mathrm{a}}$ & $24.00 \pm 0.58^{\mathrm{a}}$ \\
ANOVA & 65.015 & 5.444 & 12.669 & 15.996 & 42.892 & 35.142 \\
p-value & $<0.001^{* *}$ & $<0.008^{* *}$ & $<0.001 * *$ & $<0.001^{* *}$ & $<0.001^{* *}$ & $<0.001^{* *}$ \\
\hline
\end{tabular}

Values are means of triplicate readings. Mean values were separated using Duncan's Multiple Range Test. Mean values with different superscripts in the same column are significantly different.

$*$ = significant difference exists at $\mathrm{p} \leq 0.05$

$* *=$ significant difference exists at $\mathrm{p} \leq 0.01$

t-Test Profile of Aqueous and Ethanolic Extracts at different Concentration on the Test Organisms

\begin{tabular}{|c|c|c|c|c|c|c|c|}
\hline \multirow{2}{*}{$\begin{array}{l}\text { Concentration } \\
\left(\mathbf{m g} / \mathrm{cm}^{3}\right)\end{array}$} & \multirow{2}{*}{ Extract } & \multicolumn{6}{|c|}{ Mean \pm SEM } \\
\hline & & S. aureus & S. pneumoniae & B. cereus & E. coli & S. Typhi & S. dysenteriae \\
\hline \multirow[t]{4}{*}{400} & Aqueous & $19.00 \pm 0.58$ & $20.00 \pm 1.15$ & $12.00 \pm 1.15$ & $11.50 \pm 0.87$ & $13.00 \pm 1.15$ & $18.00 \pm 0.58$ \\
\hline & Ethanolic & $18.33 \pm 0.17$ & $13.00 \pm 2.31$ & $12.00 \pm 1.15$ & $11.33 \pm 0.88$ & $16.00 \pm 0.58$ & $15.50 \pm 0.87$ \\
\hline & t-test & 1.109 & 2.711 & 0.000 & 0.315 & -2.324 & 2.402 \\
\hline & $\mathrm{p}$-value & 0.369 & 0.075 & 1.000 & 0.899 & 0.104 & 0.084 \\
\hline \multirow[t]{4}{*}{200} & Aqueous & $18.00 \pm 0.87$ & $17.00 \pm 0.58$ & $11.00 \pm 1.15$ & $11.00 \pm 1.15$ & $11.00 \pm 1.15$ & $17.00 \pm 1.15$ \\
\hline & Ethanolic & $17.67 \pm 0.73$ & $12.00 \pm 1.15$ & $11.33 \pm 0.88$ & $10.50 \pm 0.87$ & $12.00 \pm 1.15$ & $12.00 \pm 1.15$ \\
\hline & t-test & 0.295 & 3.873 & -0.229 & 0.346 & -0.612 & 3.062 \\
\hline & $\mathrm{p}$-value & 0.783 & $0.032 *$ & 0.831 & 0.748 & 0.573 & 0.038* \\
\hline \multirow[t]{4}{*}{100} & Aqueous & $18.00 \pm 0.58$ & $11.50 \pm 0.87$ & $10.50 \pm 0.87$ & $10.00 \pm 0.00$ & $10.00 \pm 0.00$ & $14.00 \pm 1.73$ \\
\hline & Ethanolic & $12.00 \pm 1.15$ & $10.00 \pm 0.00$ & $10.00 \pm 0.00$ & $9.00 \pm 0.58$ & $10.00 \pm 0.00$ & $12.00 \pm 1.15$ \\
\hline & t-test & 3.873 & 1.732 & 0.577 & 1.732 & - & 0.961 \\
\hline & p-value & $0.032 *$ & 0.225 & 0.622 & 0.225 & - & 0.398 \\
\hline \multirow[t]{4}{*}{50} & Aqueous & $16.00 \pm 0.50$ & $11.00 \pm 1.15$ & $8.00 \pm 1.15$ & $10.00 \pm 0.00$ & $7.00 \pm 0.58$ & $12.33 \pm 0.88$ \\
\hline & Ethanolic & $11.33 \pm 0.88$ & $9.50 \pm 0.87$ & $9.00 \pm 0.58$ & $8.00 \pm 1.15$ & $7.00 \pm 0.58$ & $11.33 \pm 0.88$ \\
\hline & t-test & 4.603 & 1.039 & -0.775 & 1.732 & 0.000 & 0.802 \\
\hline & p-value & $0.017 *$ & 0.362 & 0.496 & 0.225 & 1.000 & 0.468 \\
\hline \multirow[t]{2}{*}{25} & Aqueous & $8.00 \pm 1.15$ & $9.00 \pm 0.58$ & $7.00 \pm 0.58$ & $7.00 \pm 0.58$ & $6.00 \pm 0.58$ & $9.00 \pm 0.58$ \\
\hline & Ethanolic & $10.00 \pm 0.00$ & $8.00 \pm 1.15$ & $8.50 \pm 0.87$ & $7.00 \pm 0.58$ & $6.50 \pm 0.87$ & $9.00 \pm 0.58$ \\
\hline ANOVA & t-test & -1.732 & 0.775 & -1.441 & 0.000 & -0.480 & 0.000 \\
\hline $\mathrm{p}$-value & p-value & 0.225 & 0.496 & 0.233 & 1.000 & 0.660 & 1.000 \\
\hline
\end{tabular}

$*=$ significant difference exists at $\mathrm{p} \leq 0.05$

$* *=$ significant difference exists at $\mathrm{p} \leq 0.01$

Table 5: Minimum Inhibitory Concentration (MIC) of the Extracts

\begin{tabular}{llcc}
\hline Organisms & water extract & ethanol extracts & N-hexane extract \\
\hline Staphylococcus arueus & 200 & 100 & 200 \\
Streptococcus pnuemoniae & 50 & 25 & 100 \\
Bacillus cereus & 100 & 200 & - \\
Escherichia coli & 25 & 25 & - \\
Salmonella typhi & 200 & 100 & - \\
Shigella dysenteriae & 25 & 25 & - \\
\hline
\end{tabular}

Table 6: Minimum Bactericidal Concentration (MBC)

\begin{tabular}{lccc}
\hline Organism & water extract & ethanol extracts & N-hexane extract \\
\hline Staphylococcus arueus, & $>400$ & $>400$ & $>400$ \\
Streptococcus pnuemoniae & 200 & 25 & $>400$ \\
Bacillus cereus & $>400$ & $>400$ & - \\
Escherichia coli & 100 & 25 & - \\
Salmonella typhi & $>400$ & $>400$ & - \\
Shigella dysenteriae & 25 & $>400$ &
\end{tabular}

$(>)=$ greater than 


\subsection{Proximate Composition}

\section{IV.Discussion}

Chemical and physical analyses contribute to determine the nutritive value and have been suggested as alternative ways to determine quality of feedstuffs $[12,20]$. Proximate analysis is a useful screening either for the potential of the array of nutritive estimation utilized by indigenous farmers for tropical browses /ruminant feeding [12] or for pharmaceutical preparations even though Crinum zeylanicum have effect on livestock (animals). In Senegal, Mali and Guinea, the plant is commonly known as poison and is recognized as causing diarrhea that is difficult to control. Thus in Senegal, it is not put into oral medicine [4].

The chemical composition of Crinum zeylanicum bulb is shown in Table 1. The result showed that $\mathrm{C}$. zeylanicum bulb has relatively low but high moisture content of $39.58 \%$ as compare with earlier reported work by [21]. This was expected because $C$. zeylanicum can be grown from dormant bulbs gathered during dry season on a temperate and warm temperate region [5]. For such survival, it is an indication that it has a good shelf life and it moisture sap resists microbial growth. The ash content of $6.26 \%$ is an evident that the bulb of the plant has a measureable amount of minerals, also important in the evaluation of purity of drugs showing the presence or absence of foreign organic matter such as metallic salt and silica [22] as implicated in it usage in herbal medicine. The crude fiber content $(26.55 \%)$ is relatively high. It shows that C. zeylanicum bulb contain moderate fibrous and indigestible carbohydrate. However, high fiber content reduces minerals, protein and carbohydrate bioavailability by hindering their hydrolytic breakdown [23]. The value of the crude fat $(5.00 \%)$ is sufficient, providing 1-2\% of its caloric energy as fat is said to be sufficient to human being [23]. This could be the reason why the plant aid healing of broken bone. The total carbohydrate content (43.95\%) is high and is a good source of carbohydrate, which is very useful as it contributes to the caloric value of the body/ bones while reducing sugar is an indication of the presence of hydrolysable sugar for easy absorption. The crude protein content (3.19\%) is low because of its high crude fiber as stated. According to [24], proteins from plant sources have lower quality and can be easily source. However, the bulb contain $(0.51 \%)$ of Nitrogen can be generally accepted due to it mode of consumption and supplement.

\subsection{Antibacterial Activity.}

The antibacterial profiles of C. zeylanicum bulb are shown in Tables 2-6. This study showed that the bulb of $C$. zeylanicum is an effective inhibitor of bacterial growth as it showed varies degrees of activity against the test organisms. Studying the activity of aqueous extract in Table 2, it is clear that there was significant difference in the activity of the aqueous extract and shows that the extract can be exploit as antibacterial agent. This result agrees with the conclusion of [2] stating that herbal medicine do not differ greatly from convectional drug on how they work. Also in accordance with the herbal traditional practices uses non-solvent, but the water absorbed in the bulb served as the aqueous used in this study. The Aqueous extract exhibited marked inhibitory activity against $S$. pnenmoniae at $400 \mathrm{mg} / \mathrm{cm}^{3}$, more effective than the control

There was also significant difference in the antibacterial activity of ethanol extract (Table 3) on Gramnegative and Gram-positive bacteria despite the different in their cell wall component. This action places the extract on high antibacterial value that can be harnessed in the treatment of antibiotic-resistance bacteria. [25] had earlier reported some effective agents' compounds that have antifungal, antibacterial and antiseptics activities. These activities necessitate fast healing processes of any trouble skin. The medicinal potency of the plant also has been reported, particularly as antidepressants, disinfectant and as solvents for aiding the penetration of essential oils $[26,27]$. The n-hexane extract of the bulb showed no activity on the test organisms except for $S$. pneumoniae in $\left(400-50 \mathrm{mg} / \mathrm{cm}^{3}\right)$ concentrations and at $400 \mathrm{mg} / \mathrm{cm}^{3}$ for $S$. aureus. This means that all the extracts are very potent against $S$. pneumonia which also translates to its associated infections. The results of the test for MIC revealed that S. pneumonia, E. coli and S. dysenteriae (between 25 and $50 \mathrm{mg} / \mathrm{cm}^{3}$ ) were lower than that of S. aureus, B.cereus and S. typhi (between 100 and $200 \mathrm{mg} / \mathrm{cm}^{3}$ ). This denote that the extracts of aqueous and ethanol showed potent activity on S. pneumonia, E. coli and $S$. dysenteriae but higher doses of the antibacterial agents will be required in infections caused by $S$. aureus, B.cereus and $S$. typhi provided they are not toxic to the tissues [28] However, the MBC for the three extracts revealed that water extract showed a higher potential of preventing the activity of the bacteria at 25,100 and $200 \mathrm{mg} / \mathrm{cm}^{3}$ on $S$. dysenteriae, E. coli and $S$. pneumonia respectively, while E. coli and S. pneumonia were bacteriostatic at $25 \mathrm{mg} / \mathrm{cm}^{3}$ for the ethanol extract. n-hexane extract and other test organisms were effective at greater than $\left(>400 \mathrm{mg} / \mathrm{cm}^{3}\right)$ concentrations. In addition to the above findings, it is obvious that the n-hexane extract is only sensitive to the gram positive bacteria, The differences in antibacterial activities of the extract suggest the susceptibility of microorganisms to various chemical components of the extracts. The results is in support of [29] who have established that the differences observed in antimicrobial activities suggest the susceptibility of microorganisms to various chemical components of the oil. 


\section{Conclusion}

The results of this study agrees that the nutritive value and antibacterial effects of $C$. zeylanicum bulb has the potentials for use as non convectional applications to meet the need of increasing development of resistant mutant bacteria pathogen of synthetic antibiotics and to supporting our alternative phyto-based plants for trouble skin and bone setting/healing. There is need to expand this study to other nutrients and antinutritional factors to know the extent of it effect on livestock, this will contribute greatly to the development of new pharmaceuticals, as it is not put to oral use.

\section{References}

[1] Fabricant D.S. and Farnsworth N.R. "The value of plants used in traditional medicine for drug discovery". Environ. Health Perspect. 109 Suppl 1: 2001, 69-75. doi:10.1289/ehp.01109s169. PMC 1240543. PMID 11250806.

[2] Wuzella G., Mahendran A.R., Bätge T., Jury S. and Kandelbauer A. Novel, binder-free fibre reinforce, composites based on a renewable resources from the reed-like plant Typha. Industrial Crops and Products 33 (3): 2011, 683-689

[3] Lister P.D., Wolter D.J. and Hanson N.D. Antibacterial-resistant Pseudomonas aeruginosa: Clinical impact and complex regulation of chromosomally encoded resistance mechanisms. Clinical Micro-biology Revision 22(4):2009, 582-610. https://doi.org/10.1128/CMR.00040-09.

[4] Burkill H.M. (1985). The useful plants of west tropical Africa. Families (A-D) 2nd Ed. Royal Botanical Gardens Kew. 1985, pp 6267.

[5] Yakandawala D.M.D. and Samarakoon T.M. An empirical study on the taxonomy of Crinum zeylanicum L. and Crinum latifolium L., Amaryllidaceae, Occurring in Sri Lanka. Ceylon J Sci Biol Sci 35(1): 2006, 53-72.

[6] Strahil B., Stefani R., Maria H., Frances V., Carles C., Georgi M., Iliana I. and James B. Anti-proliferative alkaloids from Crinum zeylanicum. Phytother Res 25: 2011, 1686-1692.

[7] Tsuda Y., Kashiwaba N. and Kumar V. The alkaloidal constituents of Goda Manel (Crinum Zeylanicum). Chem Pharm Bull 32: 1984, 3023-3027.

[8] Chifundera K. Baluku B. and Mashimango B. Phytochemical screening and mulluscicidal potency of some Zairean medicinal plants. LabMed Plants Herpetol 28(4): 1993, 333-340.

[9] Doepke W., Reich E and Sewerin E Zeylamine a new alkaloid from Crinum zeylanicum. Z Chemie 26: $1986,438$.

[10] Refaat J., Abdel-Lateff A., Kamel M. S., Ali A. A., Ramadan M.A., Kino and Nogata Y. Antifouling alkaloida from Crinum augustum (Amaryllidaceae). Pheog Res. 1: 2009, 43-52

[11] Tijani A.Y., Salawu O. A., Good-luck J., Mbah C.C., Madara A.A., Ikwuka A.C. and Chindo B. A. Wound healing activity of Crinum zeylanicum L. (Amaryllidaceae) .Phytopharmacol 3(2): 2012, 319-325

[12] Okoli I.C., Anunobi M.O., Obua B.E. and Enemuo V. Studies on selected browses of Southeastern Nigeria with particular reference to their proximate and some endogenous anti-nutritional constituents. Livestock Research for Rural Development, 15(9): 2003. Retrieved from http://www.lrrd.org/lrrd15/9/okol159.htm, accessed 7/18/2015.

[13] Harborne J.B. Phytochemical methods. Aguide to modern techniques of plant analysis. $2^{\text {nd }}$ ed. Chapman and Hall, London, 1991 , pp $17-20$.

[14] AOAC, Official Methods of Analysis, 13rd ed. Association of Official Analytical Chemists. Washington DC 1980

[15] Dashak D.A., Dawang M.L. and Lucas N.B. An assessment of the proximate chemical composition of locally produced spices known as dadawa basso and dadawa kalwa from three markets in Plateau State of Nigeria. Food chemistry incorporating Journal of Micronutrient Analysis, 75: 2001, 231-235.

[16] Dashak D.A. and Shambe, T. Chemical composition of Striga hermonthica Affected and Unaffected Maize Plant. Journal of Applied Sciences, 8(2): 2005, 4850-4859.

[17] Sanchez N.R., Garcia DA., Shiavini M.S., Nakamura C.V. and Filho B.P.D. An evaluation of antibacterial activities of Psidiumguajava. Brazilian Journal of biotechnology 48: 2005, 429-436.

[18] Atlas R.M. Microorganisms in our World $2^{\text {nd }}$ edn. Mosby Publishers Inc. Baltimore, 1995, pp. 765

[19] Ochei J. and Kochatkar A. (2007) Medical Laboratory Science, Theory and Practice.Tata McGraw-Hill Ltd, 2007, pp. 795-817.

[20] Mokoboki H.K., Ndlovu L.R., Ng'ambi J.W., Malatje M.M. and Nikolova R.V. Nutritive value of Acacia tree foliages growing in the Limpopo Province of South Africa, South African Journal of Animal Science, 35 (4): 2005, 221-228.

[21] Dashak D. A. Ano J. Chemical composition and phytochem-ical studies of Crinum zeylanicum. Journal of Sciences Engineering and Technology 14 (2), 2007, 7355-7365.

[22] David G.O. Proximate and Phytochemical Analysis of Cajanus cajan (Pigeon Pea) Leaves. Chemical Science Transaction, 3(3): 2014, 1172-1178.

[23] Hassan L.G., Sokoto M.A., Dangoggo S.M. and Landan M.J. Proximate, Amino Acids and Compositions of Silk Cotton Seeds (Ceiba pentandra L.) Africa Journal of Natural Sciences, 9: 2006, 29-35

[24] Bwai M.D., Afolayan M., Odukomaiya D., Ikokoh P.and Orishadipe A. Proximate composition, mineral and phytochemical constituents of Eleusine coracana (finger millet). International Journal of Advance Chemistry, 2(2): 2014, 171-174

[25] Daben J.M. and Dashak D.A. Extraction, isolation and mass spectral analysis of Crinum zeylanicum (beautiful crinum) bulbs. Ew J HerbChem Pharmacol Res 3(1): 2016, 52-58.

[26] Jorg F., Ulrich G. and Thomas A.S. 'Xylene in Ullmann's Encyclopedia of Industrial Chemistry. Wiley-VCH, Weinhiem, 2002, pp. 28-433.

[27] Cruz S., Chavez P.P., Martine Z.N. and Lopez R.C. Toluene has antidepressant-like actions in two animal models used for screening of antidepressant drugs. Psychopharmacol 204(2): 2009, 279-286.

[28] Adeniyi B.A. and Ayepola O.O. The phytochemical screening and antimicrobial activity of leaf extracts of eucalyptus camaldulensis and eucalyptustorelliana / (myrtaceae). Research Journal of Medic-inal Plants 2: 2008, 34-38. https://doi.org/10.3923/rjmp.2008.34.38.

[29] Russo M., Suraci F., Postorino S., Serra D., Roccotelli A. and Giovanni E. A. Essential oil chemical composition and antifungal effects On Sclerotium cepivorum of Thymus capitatus wild populations from Calabria, southern Italy. Revista Brasileira de Farmacognosia 23(2): 2013, 239-248. 